\title{
MODIFIED DESCRIPTION OF SOIL PROCESSES VS. QUALITY OF NUMERICAL WEATHER FORECASTS - "BARE SOIL" CASE
}

\author{
ZMODYFIKOWANY OPIS PROCESÓW GLEBOWYCH \\ A JAKOŚĆ PROGNOZ NUMERYCZNYCH - PRZYPADEK ,GOŁEJ GLEBY”
}

\begin{abstract}
Soil and atmosphere boundary layer (ABL) interact with each other and influence on physical processes in soil and atmosphere. Current parameterization of soil physical processes in TERRA_ML (multilayer soil module of COSMO meteorological model) was prepared more than 40 years ago and did not give satisfactory forecast results. New parameterizations should involve physical processes in the soil (microphysics processes in soil, fluid dynamics in porous media, soil dynamics, etc.), water cycle in soil and soil-plant-water relation. The aim of this project was to improve current soil parameterization in the COSMO model, called "TERRA_ML". The results of the work, related to the parameterization of physical processes of bare soil evaporation, vertical and horizontal water transport in soil and a runoff from soil layers, are presented in this paper. In order to eliminate underestimation of evaporation from soil in the afternoon and overestimation evaporation from soil in the morning a correction time-depending factor was also introduced. In this way, theoretical description of vertical water transport in soil is improved with temperature dependency of hydraulic diffusivity for different sort of soil.
\end{abstract}

Keywords: soil processes, parameterization, meteorological forecasts, numerical modeling, multilayer soil model

\section{Multi-layer soil module in COSMO model}

The physical processes occur in the soil on a scale smaller than the resolution of domain in numerical weather models. These processes must be parameterized if one need to specify their impact on a larger scale phenomena in the atmosphere. Hydrological and thermal processes in soil have a significant impact on phenomena occurring in atmosphere boundary layer [1]. This is why they are very important to accurately reproduce the actual condition of soil. On the other hand, a better understanding of the hydrodynamics of soil (an environment consisting of porous media), and improvement of its representation in numerical models will lead to better quality of forecast of various kinds, including forecasts of pollutants dispersion in ground and in the atmosphere, soil profiles (ie profiles of water content in soil, profile of concentration of pollutants, temperature profile etc.). Until now, parameterizations in all meteorological models are not good enough, as far as thermal and hydrological processes in soil are concerned [2,3]. Most of parameterizations are based on

\footnotetext{
${ }^{1}$ Institute of Meteorology and Water Management - National Research Institute, ul. Podleśna 61, 01-673 Warszawa, Poland, phone +48 2256941 34, fax +48 2256943 56, email: grzegorz.duniec@imgw.pl

* Corresponding author: andrzej.mazur@imgw.pl
} 
the numerical experiments rather than in-depth understanding of the soil phenomena. The authors have attempted to verify the currently existing parameterization, hoping for a better representation of agrophysical processes in numerical models, which will result in improved meteorological, agro-physical and agro-meteorological forecasts.

The TERRA_ML parameterization in COSMO (non-hydrostatic, limited-area atmospheric model for numerical weather forecasts) accounts for the five regular soil types: sand, sandy loam, loam, loamy clay and clay, together with three special soil types: peat, ice and rock [4]. Basic soil types in Poland, as applied in COSMO model, is shown in Figure 1. One should keep in mind that for ice and rock, hydrological processes in the ground are not considered. Although potential evaporation is assumed to occur over the ice surface, yet for this kind of ground a value of soil water content, related with vertical water flow, remains unchanged.

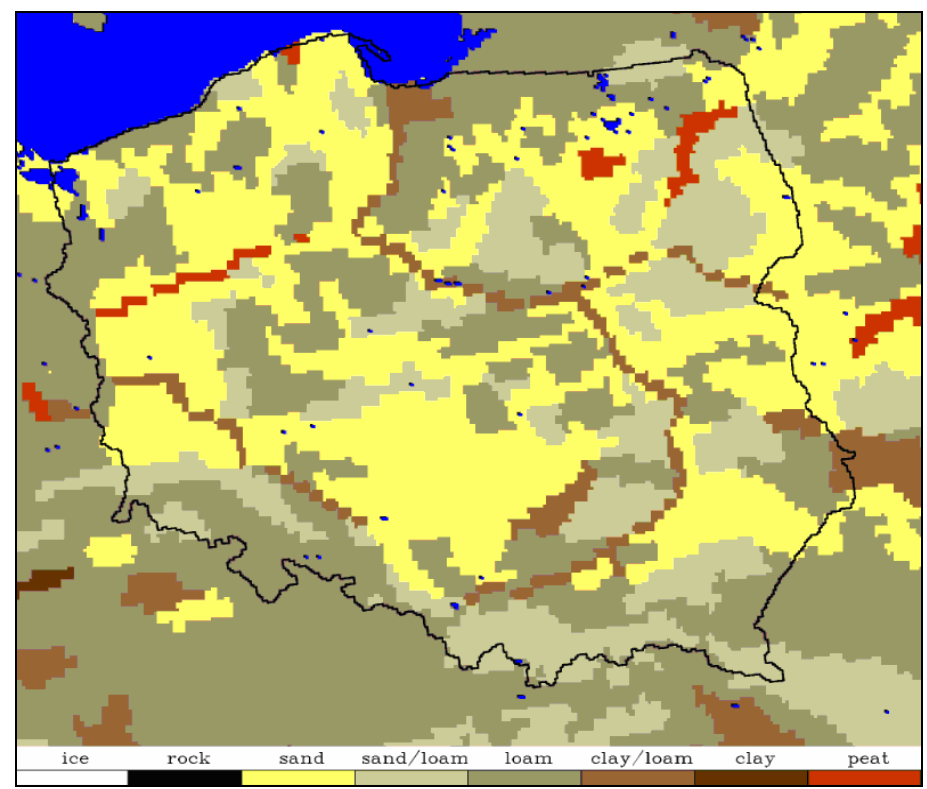

Fig. 1. Basic soil type in Poland (as applied in COSMO model). Space resolution $2.8 \mathrm{~km}$ x $2.8 \mathrm{~km}$. See text for detail explanation

The soil model consists of two parts. In the first part the computation of bare soil evaporation and plant transpiration is performed, in the second part - heat conduction and diffusion equations are solved. Calculation of snow melting is included here. In TERRA_ML six layers are introduced for water cycle and seven for thermal processes (see Fig. 2, left chart). Depth of half levels (in meters) are calculated using following formula:

$$
z_{h, k}=0.01 \cdot 3^{k-1}
$$

while center of main layer(s) is given by:

$$
z_{m, k}=0.5 \cdot\left(z_{h, k}-z_{h, k-1}\right)
$$


where $k$ is a number of active soil layer $(k=1,2, \ldots, 6$ for hydrological processes and 1-7 for thermal processes). Total layer of thermal active soil has thickness of $7.29 \mathrm{~m}$, while hydrological active soil - $2.43 \mathrm{~m}$. In this parameterization only hydrological (evapo-transpiration, interception reservoir, infiltration of rain etc. - Figure 2, center chart) and thermal (temperature of snow-free and snow-covered soil, snow albedo, melting and thawing etc. - Figure 2, right chart) processes are considered and capillary transport is neglected).

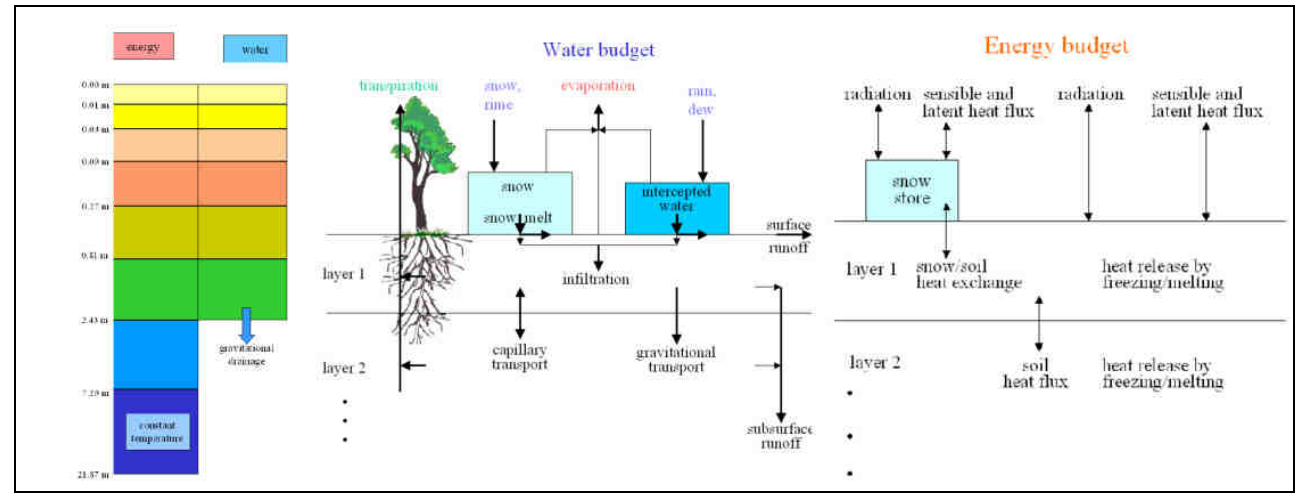

Fig. 2. Level distribution for water and energy processes in soil model (left chart). Hydrological and thermodynamic processes in soil (center and right chart, respectively) included in TERRA_ML [4]

Hydrological processes in soil are described with mass budget equations (see [4]):

$$
\begin{gathered}
\rho_{w} \frac{\partial \theta_{i}}{\partial t}=\alpha P_{r}+E_{i}-I_{\text {perc }}-R_{\text {int } e r} \\
\rho_{w} \frac{\partial \theta_{\text {snow }}}{\partial t}=P_{\text {snow }}+E_{\text {snow }}-I_{\text {snow }}-R_{\text {snow }} \\
\rho_{w} \frac{\partial \theta_{l, k}}{\partial t}=\delta_{1, k}\left[(1-\alpha) P_{r}+E_{b}+I_{\text {perc }}+I_{\text {snow }}-R_{\text {inf } i l}\right]+F_{k, k+1}-\left(1-\delta_{1, k}\right) \cdot F_{k-1, k}+\operatorname{Tr}_{k}-R_{k}+S_{k} \\
\rho_{w} \frac{\partial \theta_{\text {ice }, k}}{\partial t}=-S_{k}
\end{gathered}
$$

where: $\rho_{w}$ - density of water, $\theta_{i}$, $\theta_{\text {snow }}$ - water content of interception and snow reservoir, $\theta_{l, k}$ - liquid water content of soil layer, $\theta_{i c e, k}$ - ice content of soil layer, $E_{i}, E_{\text {snow }}$ - evaporation from interception and snow reservoir, $E_{b}$ - evaporation from bare soil, $\operatorname{Tr}_{k}$ - water extraction by roots, $P_{r}, P_{\text {snow }}$ - precipitation rate of rain and snow, $\alpha$ - factor for distributing rain between interception reservoir and infiltration, $I_{\text {perc }}, I_{\text {snow }}$ - infiltration contributions from percolation and from melting snow, $R_{\text {inter }}, R_{\text {snow }}, R_{\text {infil }}$ - run-off from interception, from snow reservoir and from limited infiltration rate, $R_{k}$ - runoff from soil layers, $F_{k, k+1}$ - gravitational and capillary flux of water between layers $k+1$ and $k, S_{k}$ - source term of liquid water by thawing soil ice.

All right-hand-side terms in formulas (3)-(6) are parameterized. Details of these parameterization it can be found in COSMO model manual [4]. 
In this paper only evaporation from bare soil is considered and this process is described as follows:

$$
E_{b}=\left(1-f_{i}\right) \cdot\left(1-f_{\text {snow }}\right) \cdot\left(1-f_{\text {plant }}\right) \cdot \min \left[-E_{\text {pot }}\left(T_{\text {sfc }}\right), F_{m}\right\rfloor
$$

where $f_{i}, f_{\text {snow }}, f_{\text {plant }}$ is the fractional area covered by interception water, by snow, or by plants, respectively, $E_{p o t}$ - potential evaporation, $F_{m}$ - is the maximum moisture flux through the surface [1].

Maximum moisture flux through the surface is described by following formula (Dickinson's parameterization [1]):

$$
E_{b}=\rho_{w}\left(1+1550 \cdot \frac{D_{\min }}{D_{\max }} \cdot \frac{B-3.7+\frac{5}{B}}{B+5}\right) \cdot 1.02 \cdot D_{\max } s_{u}^{B+2}\left(\frac{s_{t}}{s_{u}}\right)^{\left\{5.5-0.8 B\left[1+0.1(B-4) \log \frac{K_{0}}{K_{r}}\right]\right\}} \frac{s_{t}}{\sqrt{z_{u} z_{t}}}
$$

where $D_{\min }=2.5 \cdot 10^{-10} \mathrm{~m}^{2} / \mathrm{s}-$ minimum soil diffusivity, $D_{\max }=B \Phi_{0} K_{0} / \rho_{w m}-$ maximum diffusivity, $K_{r}=10^{-5} \mathrm{~m} / \mathrm{s}, K_{0}$ - maximum hydraulic conductivity, $\Phi_{0}=0.2 \mathrm{~m}$ (soil suction), $\rho_{w m}=0.8$, fraction of saturated soil filled by water, nominally 0.5 [1], $B$ - non-dimensional parameter depending on type of soil, $s_{w}, s_{t}$-average of soil water content normalized by the volume of voids for uppermost layer $(0.1 \mathrm{~m}$ thickness $)$ and for a total active layer $(1 \mathrm{~m}$ thickness), respectively, and $z_{w}, z_{t}$ - uppermost and total active layer, respectively.

Dickinson suggested that mathematical general formula which described maximum moisture flux through the surface was derived from dimensional analysis and physical properties, but the details of the formulas used appear to be based on numerical experiments [1].

\section{Changing parameterization of water flux through soil layers}

Based on analysis of soil water content profiles for different type of soil [5] authors concluded that present parameterization cannot produce satisfactory results. This parameterization was prepared for a meteorological model with low domain resolution. Nowadays numerical models work with much higher resolution and hence an adequate correction of parameterization is strongly recommended.

This paper has presented new results for modified formula for maximum moisture flux through the soil surface. Dickinson's parameterization was replaced by Darcy equation:

$$
\vec{F}=-D(\theta) \vec{\nabla}(\theta)
$$

with $D(\theta)$ being hydraulic diffusivity, parameter dependent on soil water content.

In the next step Darcy equation (9) was modified by insertion of water viscosity which should influence on the transport of water in soil. Because of temperature dependence of the viscosity, influence of soil temperature on water flow in porous media should be observed. Thus, six different options were considered (called as modified Darcy equation, $M D E)$ :

$$
\vec{F}=-D(\theta)\left(\frac{T}{T_{0}}\right)^{a} \vec{\nabla}(\theta)
$$




$$
\vec{F}=-D(\theta) \cdot \exp \left(\frac{T}{T_{0}}\right) \vec{\nabla}(\theta)
$$

with $T$ - being actual soil temperature, $T_{0}=273.15 \mathrm{~K}$, parameter $a$ was equal to $-1,0,0.5,1$ and 2 . For these values of $a$ numerical experiments were carried out.

As indicated earlier Dickinson's parameterization of water flow through the soil [1] overestimates a value of evaporation rate at sunrise about $50 \%$ and underestimates it by $20 \%$ at sunset. Assuming the parabolic form of adequate correction factor to minimize this under- and overestimation, authors suggested following form of correction factor:

$$
\alpha(t)=-\frac{0.7}{t_{z}^{2}-t_{w}^{2}}+\frac{1.5 \cdot t_{z}^{2}-0.8 \cdot t_{w}^{2}}{t_{z}^{2}-t_{w}^{2}}
$$

where $t_{w}, t_{z}$ - the time of sunrise and sunset, respectively.

Taking these considerations into account, a modified Darcy equation will have the following form:

$$
\vec{F}=-\alpha(t) \cdot D(\theta)\left(\frac{T}{T_{0}}\right)^{a} \vec{\nabla}(\theta)
$$

or

$$
\vec{F}=-\alpha(t) \cdot D(\theta) \cdot \exp \left(\frac{T}{T_{0}}\right) \vec{\nabla}(\theta)
$$

Temperature-dependent $\left(T / T_{0}\right)^{a}$ was additionally applied to “old" Dickinson's parameterization (8) [4]:

$$
\begin{aligned}
& E_{b}=\rho_{w}\left(1+1550 \cdot \frac{D_{\min }}{D_{\max }} \cdot \frac{B-3.7+\frac{5}{B}}{B+5}\right) \\
& \cdot 1.02 \cdot D_{\max } s_{u}^{B+2}\left(\frac{s_{t}}{s_{u}}\right)^{\left\{5.5-0.8 B\left[1+0.1(B-4) \log \frac{K_{0}}{K_{r}}\right]\right.} \frac{s_{t}}{\sqrt{z_{u} z_{t}}}\left(\frac{T}{T_{0}}\right)^{a}
\end{aligned}
$$

with $T$ being - actual temperature of water in porous media and $T_{0}=273.15 \mathrm{~K}$, $a$ - non-dimensional parameter depended on the type of soil, $D(\theta)$ - hydraulic diffusivity.

As above, parameter $a$ was equal to $-1.0,0,0.5,1.0$ and 2.0, and for these values numerical experiments were carried out.

\section{Numerical experiments}

Numerical experiments were split into two parts. In the first part, eleven terms of model runs were selected due to chosen meteorological conditions. All terms are listed in Table 1. All these terms were selected having in mind the conditions of the soil, atmosphere and overall synoptic situation during a particular day, as it was explained in [5].

Results of these experiments were used to establish a direct relation between values of parameter $a$ and type(s) of soil. 
In the frame of the second part of study, long-term numerical experiments were conducted for two seasons (spring and summer, from April $1^{\text {st }}$ to September $30^{\text {th }}, 2013$ ), for chosen values of parameter $a$.

Table 1

Terms selected for numerical experiments

\begin{tabular}{|c|c|c|}
\hline Date & Beginning of forecast, UTC & Season (estimated) \\
\hline February $1^{\text {st }}, 2009$ & $00: 00$ & Winter \\
\hline February $22^{\text {nd }}, 2009$ & 00:00 & Winter \\
\hline October $16^{\text {th }}, 2009$ & 00:00 & Autumn \\
\hline October $16^{\text {th }}, 2009$ & $12: 00$ & Autumn \\
\hline November $4^{\text {th }}, 2009$ & $12: 00$ & Autumn \\
\hline November $21^{\text {st }}, 2009$ & $00: 00$ & Autumn \\
\hline February $3^{\text {rd }}, 2012$ & $00: 00$ & Winter \\
\hline May $18^{\text {th }}, 2012$ & $00: 00$ & Summer \\
\hline July $1^{\text {st }}, 2012$ & 00:00 & Summer \\
\hline December $14^{\text {th }}, 2012$ & 00:00 & Winter \\
\hline December $16^{\text {th }}, 2012$ & $00: 00$ & Winter \\
\hline
\end{tabular}

For both series of the numerical experiments, the following meteorological and agrophysical fields were considered:

1. Soil Water Content (SWC) and Soil Temperature (TS) of soil at a depth of $1 \mathrm{~cm}, 2 \mathrm{~cm}$, $6 \mathrm{~cm}, 18 \mathrm{~cm}, 54 \mathrm{~cm}, 162 \mathrm{~cm}, 486 \mathrm{~cm}$ and $1458 \mathrm{~cm}$, according to distribution of vertical levels of TERRA_ML model,

2. TS and air relative humidity at surface,

3. air temperature and dew point temperature at $2 \mathrm{~m}$ a.g.l. (above ground level), air relative humidity at $2 \mathrm{~m}$ a.g.l., zonal and meridional wind at $10 \mathrm{~m}$ a.g.l.,

4. atmospheric precipitation.

Results from the first part of numerical experiments were analyzed as follows:

- results of measurements of selected meteorological elements (points 2 to 4 from above list) at meteorological stations were compared with forecasts - results of the COSMO model in an operational (reference) version,

- similarly, results of measurements were compared with products of COSMO model with various modifications of water flux (according to equations (10)-(15)) and temperature and/or time dependence,

- results of COSMO model in an operational - reference - version were compared with corresponding products of COSMO model(s) with various modifications of water flux.

\section{Results and discussion}

Based on the analysis and on the comparison between numerical experiments and observation data authors wanted to determine a relationship between a type of soil and the value of the parameter $a$ used in equation (1). As a result of the first part of numerical experiments, an influence of changing the parameterization of water flow in soil on forecasts of dew point temperature and other meteorological fields (wind speed, air temperature) was observed. Based on these data it can be stated that the best results were obtained with a water flux in the soil described by the modified Darcy equation (10) for $a$ equal to 0.5 and (similarly) by the modified Dickinson parameterization (eq. (15)). In both parameterizations a temperature dependence was also applied. Examples of analysis 
are presented for two chosen cases: first one as an example of winter season, ie February $1^{\text {st }}, 2009$ and second one as an example of summer season, July $1^{\text {st }}, 2012$.

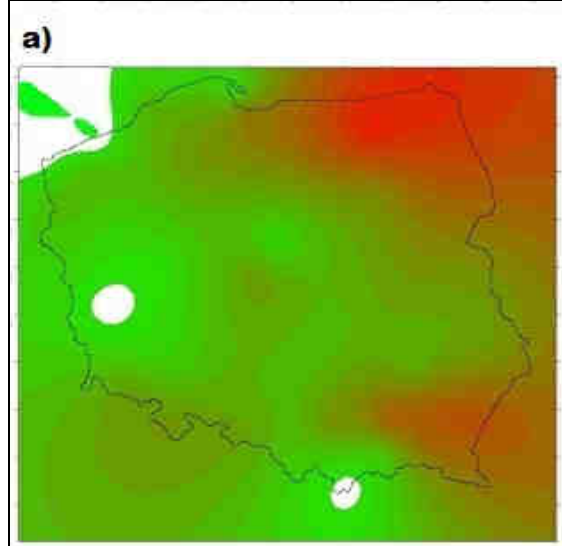

c)

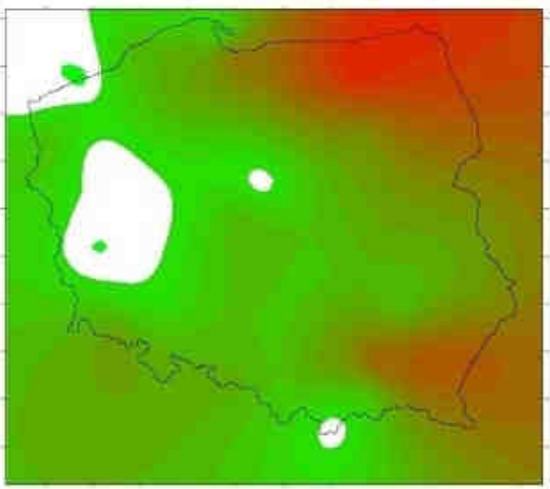

b)

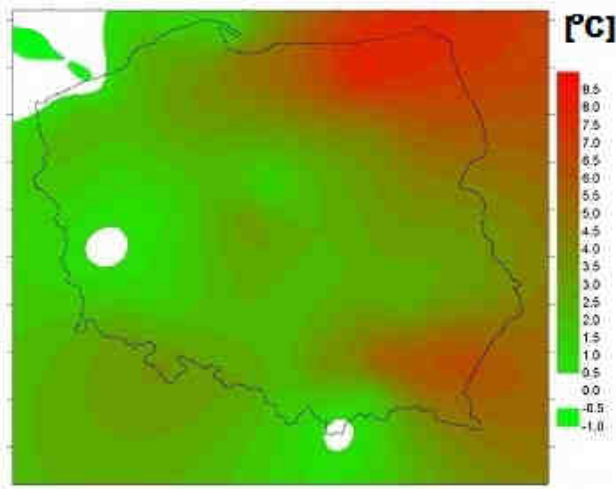

d)

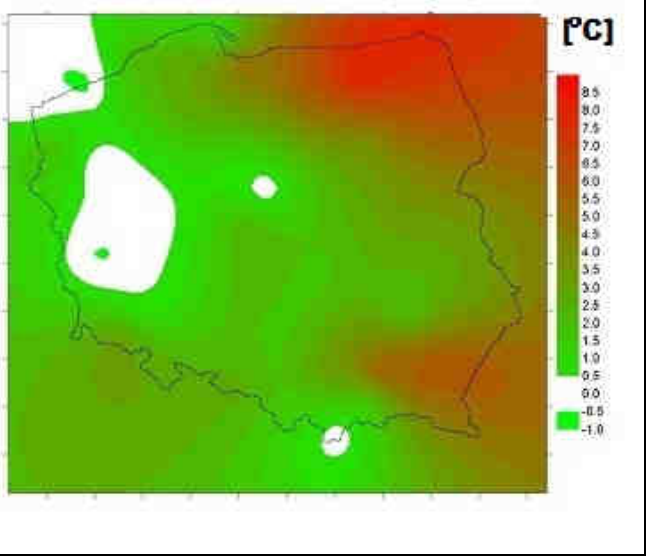

Fig. 3. Analysis of the dew point temperature forecasts (winter season - February $1^{\text {st }}$, 2009). Results for winter season, dew point temperature - differences between measurements and the forecasts of different model versions. a) Dickenson's parameterization - reference (eq. (8)), b) Darcy equation (eq. (9)), c) Darcy parameterization with temperature dependency added (eq. (10)) with an exponent $a$ equal to 0.5 , d) Dickenson's parameterization modified with dependence on temperature (eq. (15)) with an exponent $a$ equal to 0.5. Measurements from 61 Polish SYNOP stations were interpolated into regular grid using kriging method

Figure 3 shows a comparison of measurements of the dew point temperature with forecasts obtained from the reference model version (Fig. 3a) and from model with various versions of parameterization changes (Fig. 3b-d). In Figure 3b, differences between observations and forecast results from the COSMO model with parameterization changed in terms of equation (9), in Figure $3 \mathrm{c}$ - equation (10) and $a$ equal to 0.5, and in Figure $3 \mathrm{~d}$ - in terms of equation (15) with the same value of $a$. Analysis showed that dew point temperature forecasts were close to the measurements for areas with sand, sand and loam, 
loam and peat (in all panels in the figure white areas indicate regions with no differences between model forecasts and observed values). Improvement of forecast vs. observations was observed for parameterization with temperature dependence taken into account (Fig. 3c and $3 \mathrm{~d}$, equations (10) and (15), respectively).
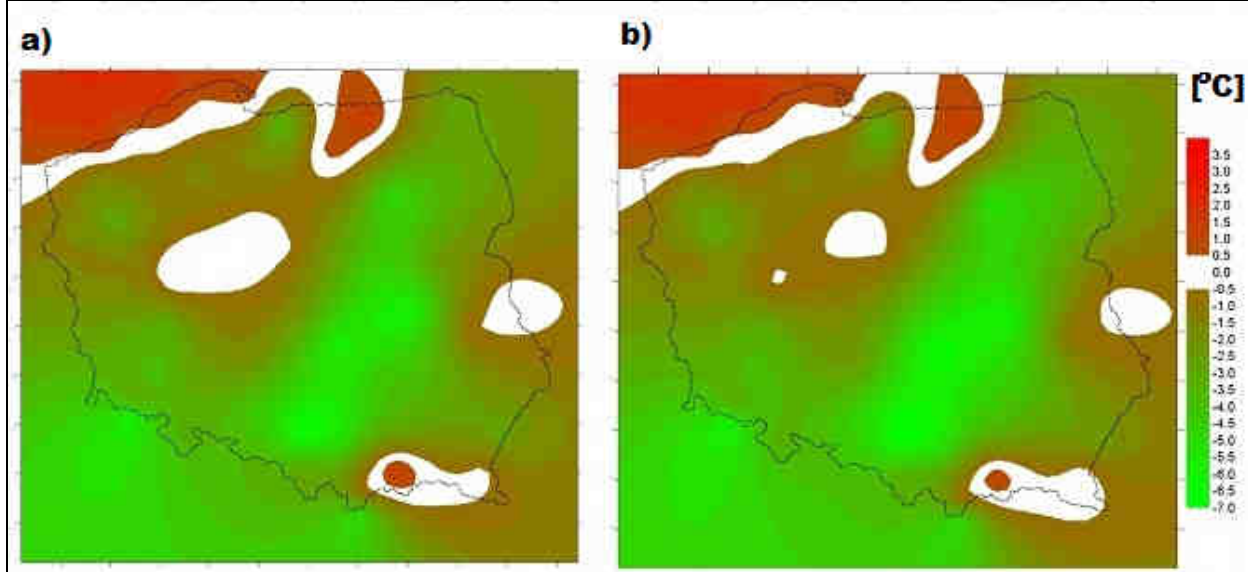

\section{c)}

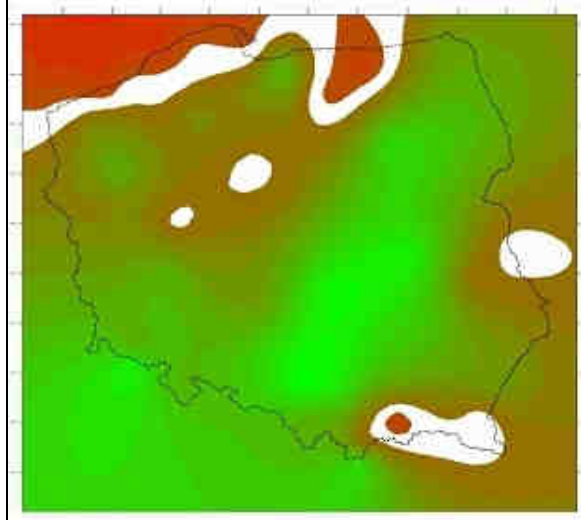

\section{d)}

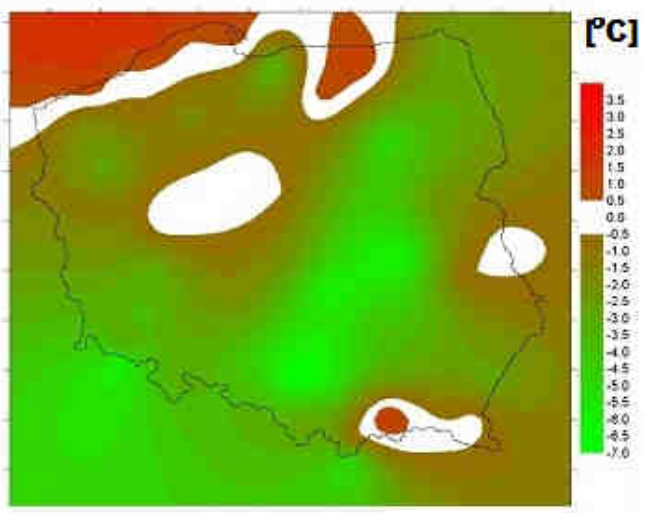

Fig. 4. Analysis of the dew point temperature forecasts (summer season - July $1^{\text {st }}$, 2012). Results for summer season, dew point temperature - differences between measurements and the forecasts of different model versions. a) Dickenson's parameterization - reference (eq. (8)), b) Darcy equation (eq. (9)), c) Darcy parameterization with temperature dependency added (eq. (10)) with exponent $a$ equal to 0.5 , d) Dickenson's parameterization modified with dependence on temperature (eq. (15)) with exponent $a$ equal to 0.5. Measurements from 61 Polish SYNOP stations were interpolated into regular grid using kriging method

During the summer season, some improvement is observed for the soil-temperature dependence (eq. 15) considered (Fig. 4a vs. Fig. 4d), yet, in general, dew point temperature forecast gets worse with revised parameterization in comparison with reference forecast. Almost identical pictures for summer season can be seen as far as air temperature or wind 
speed forecasts are concerned (Fig. 5 and 6, respectively). One can see an improvement in north-eastern part of Poland, over sands and peat soil.

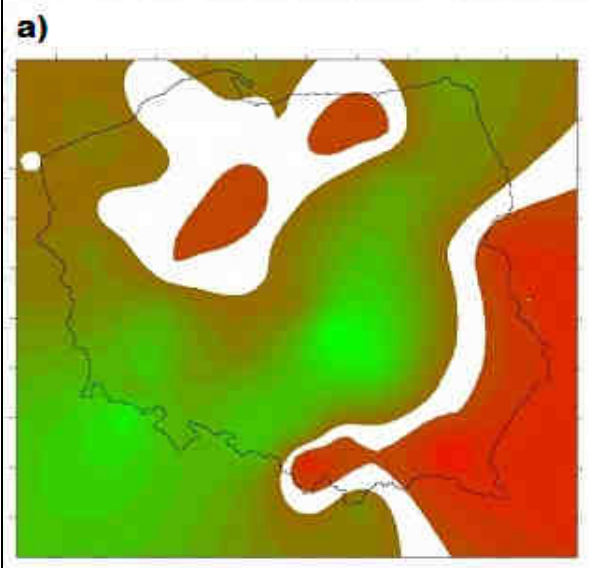

c)

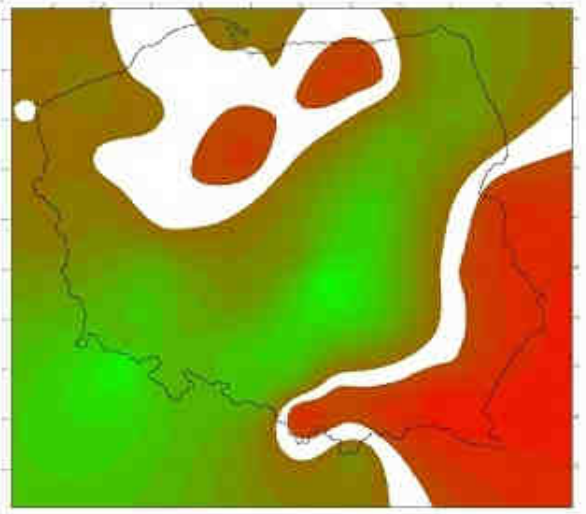

b)

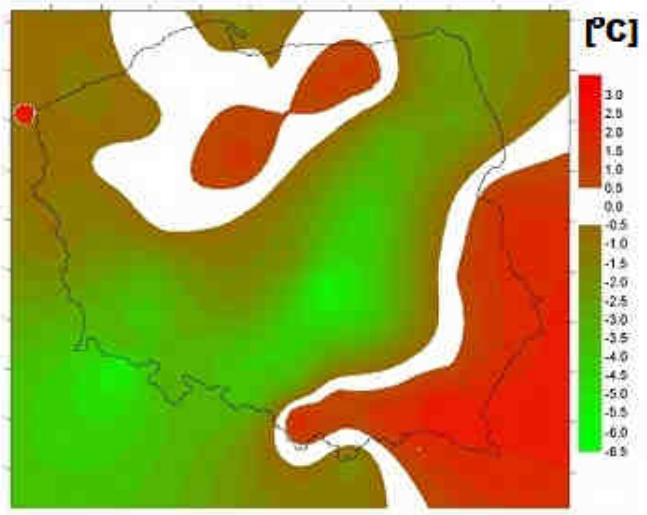

d)

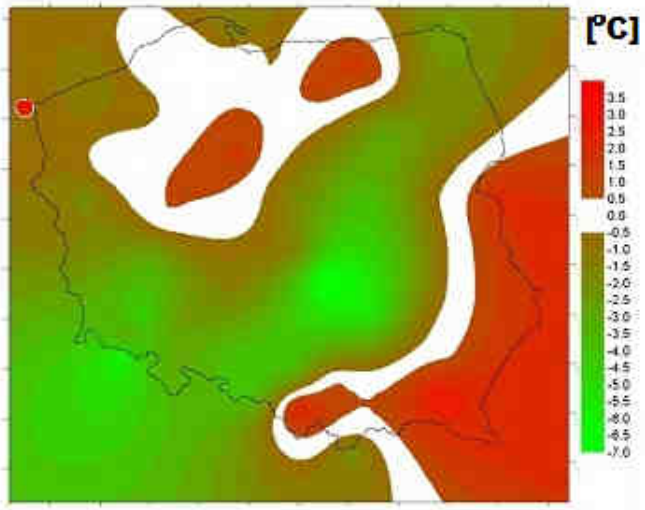

Fig. 5. Analysis of the air temperature forecasts (summer season - July $1^{\text {st }}$, 2012). Results for summer season, air temperature - differences between measurements and the forecasts of different model versions. a) Dickenson's parameterization - reference (eq. (8)), b) Darcy equation (eq. (9)), c) Darcy parameterization with temperature dependency added (eq. (10)) with exponent $a$ equal to 0.5 , d) Dickenson's parameterization modified with dependence on temperature (eq. (15)) with exponent $a$ equal to 0.5. Measurements from 61 Polish SYNOP stations were interpolated into regular grid using kriging method

Similar numerical experiments accompanied by an analysis of results were carried out for Darcy equation (eq. (9) and (10)) with reciprocal ( $a$ equal to -1$)$, linear ( $a$ equal to 1 ) and square-type ( $a$ equal to 2 ) soil temperature dependence taken into account. Not all obtained results were quite satisfactory. A global improvement during a summer season could only be seen in areas with sand and loam. For loam (in Krakow vicinity) an improvement of dew point temperature forecast was observed. On the other hand, close 
to Warszawa (sand and sand-loam soils) a deterioration of dew point forecast was observed. Worsening of forecasts during the winter season were observed in areas with sand, loam, sand-loam and peat soils.

a)

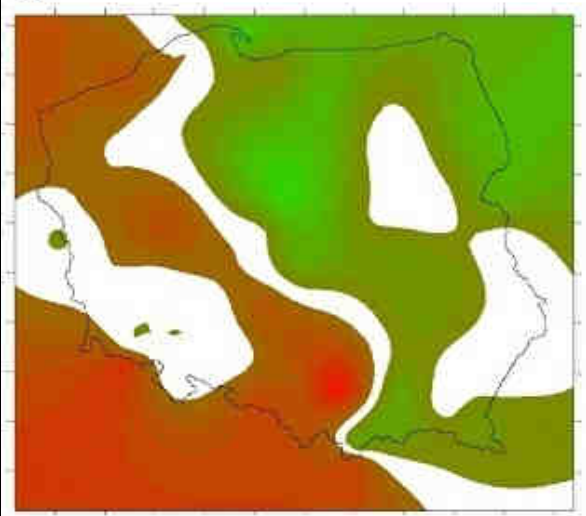

c)

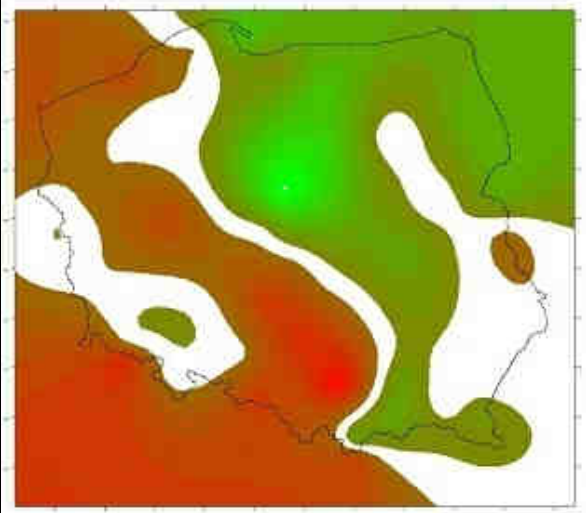

b)

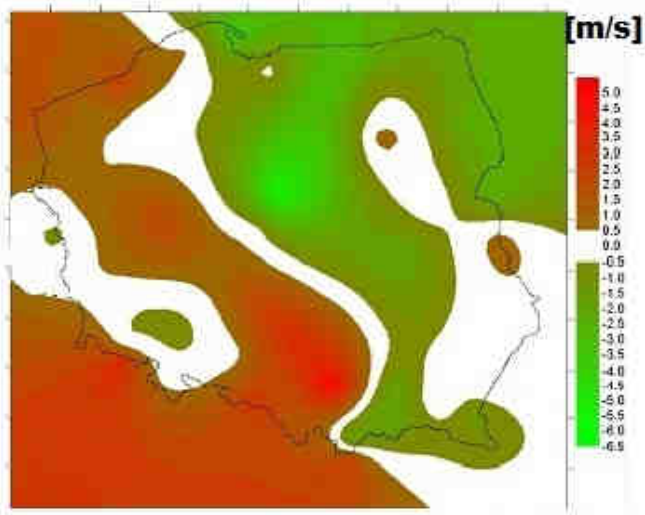

d)

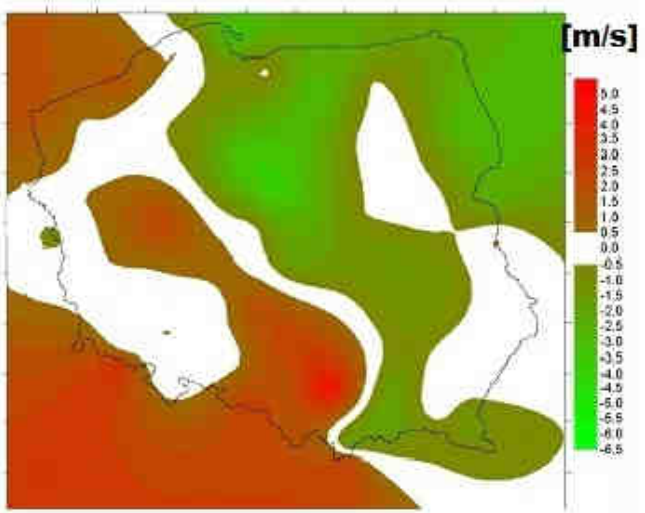

Fig. 6. Analysis of wind speed forecasts (summer season - July $1^{\text {st }}, 2012$ ). Results for summer season, wind speed - differences between measurements and the forecasts of different model versions. a) Dickenson's parameterization - reference (eq. (8)), b) Darcy equation (eq. (9)), c) Darcy parameterization with temperature dependency added (eq. (10)) with exponent $a$ equal to 0.5 , d) Dickenson's parameterization modified with dependence on temperature (eq. (15)) with exponent $a$ equal to 0.5 . Measurements from 61 Polish SYNOP stations were interpolated into regular grid using kriging method

Next, Darcy equation was modified by the introduction of the exponential function of the soil temperature (eq. (11)). Dew point temperature, air temperature and wind speed forecasts for cold and warm season were compared with measurements at meteorological stations. Unfortunately, for selected dates no improvement of dew point temperature forecast were seen, especially in cold season for sand, sand-loam nor peat soils. Air 
temperature forecasts were improved for sand, loam and peat soil during warm season, but during the winter no improvement of air temperature forecasts was detected. As far as wind speed forecasts are concerned, an improvement could be seen in the warm season for light clay, sand and sand-clay soil in the central and northern Poland, while a slight worsening was observed in areas with heavy clay soil. For the remaining part of Poland wind speed forecasts did not improve at all. In winter, no improvement of wind speed forecasts was observed.

The changed description of water flux in soil was tested for the entire warm season (spring and summer), the period of April $1^{\text {st }}$ - September $30^{\text {th }}, 2013$. Cold period (fall and winter) was not considered. For different changed parameterization of water flux through soil (in eq. (10), with $a$ equal to $-1,0,0.5$ and 2, eq. (11), eq. (13) and (14) - with time-dependent correction factor considered) forecasts of meteorological fields were, again, compared with reference forecast of an operational version of the COSMO model (with "old" unchanged Dickenson's parameterization) and with observational data from meteorological stations. Due to a great number of received results strong selection has been performed to present adequate outcomes in this paper. Figures 7-12 show forecasts of meteorological fields using changed parameterization (selected results).

From the analysis of results (eg Figs. 7-12) one could say that the forecasts of dew point temperature, air temperature and wind speed in general improved mainly in the central part of Poland with sand and loam soil (stations from $15^{\text {th }}$ to $45^{\text {th }}$ ). For both parameterization of water flow through soil (using eq. (10) for $a=0.5$ and eq. (11)) forecasts are very similar. In both cases better consistency with measurements were obtained when taking into account a time-dependent correction parameter (eq. (13) for $a=0.5$ and eq. (14)). For other parameterization considered (eq. (10) for $a=-1,1,2$ ) the results were not suitable as much as the previously mentioned ones.

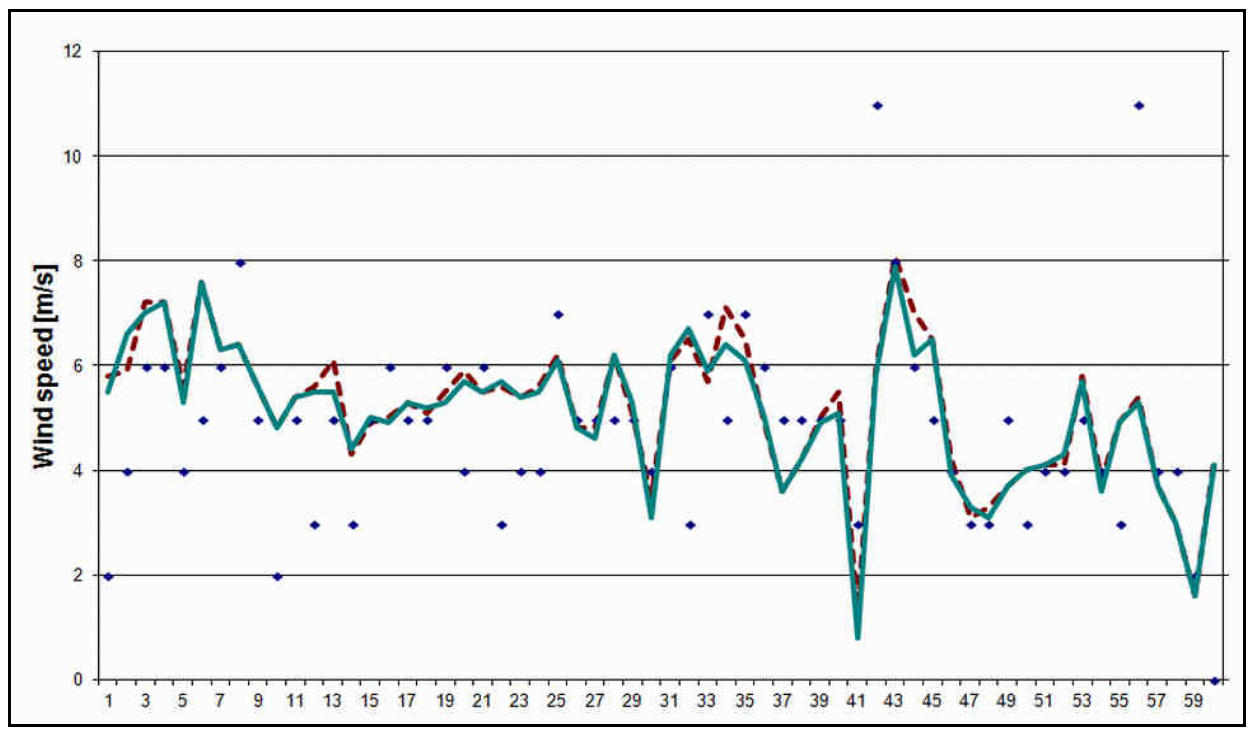

Fig. 7. Analysis of forecast of wind speed for April $15^{\text {th }}, 2013$. Blue diamonds represent values measured at meteorological stations (X axis - number of station). Green solid line: Darcy equation, with exponential temperature dependence. Red dashed line: parameterization with Darcy equation, exponential temperature dependence and the time correction coefficient considered 


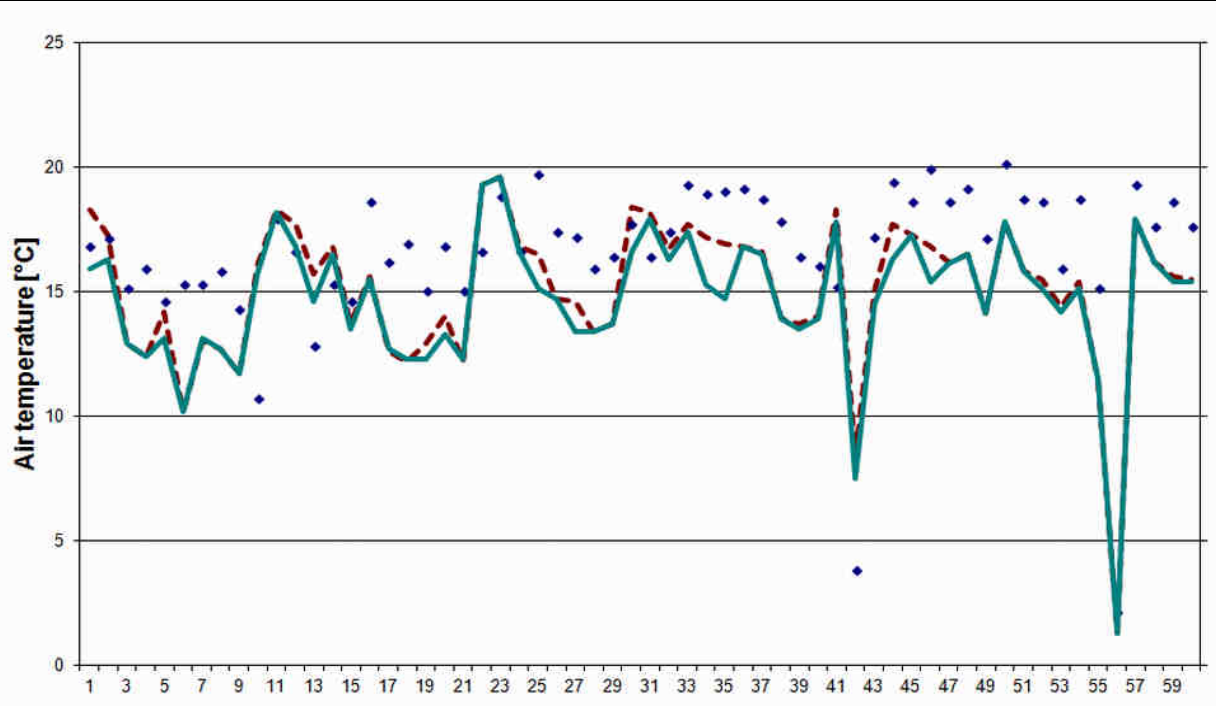

Fig. 8. Analysis of forecast of air temperature for April $15^{\text {th }}, 2013$. Blue diamonds represent values measured at meteorological stations ( $\mathrm{X}$ axis - number of station). Green solid line: Darcy equation, with exponential temperature dependence. Red dashed line: parameterization with Darcy equation, exponential temperature dependence and the time correction coefficient considered

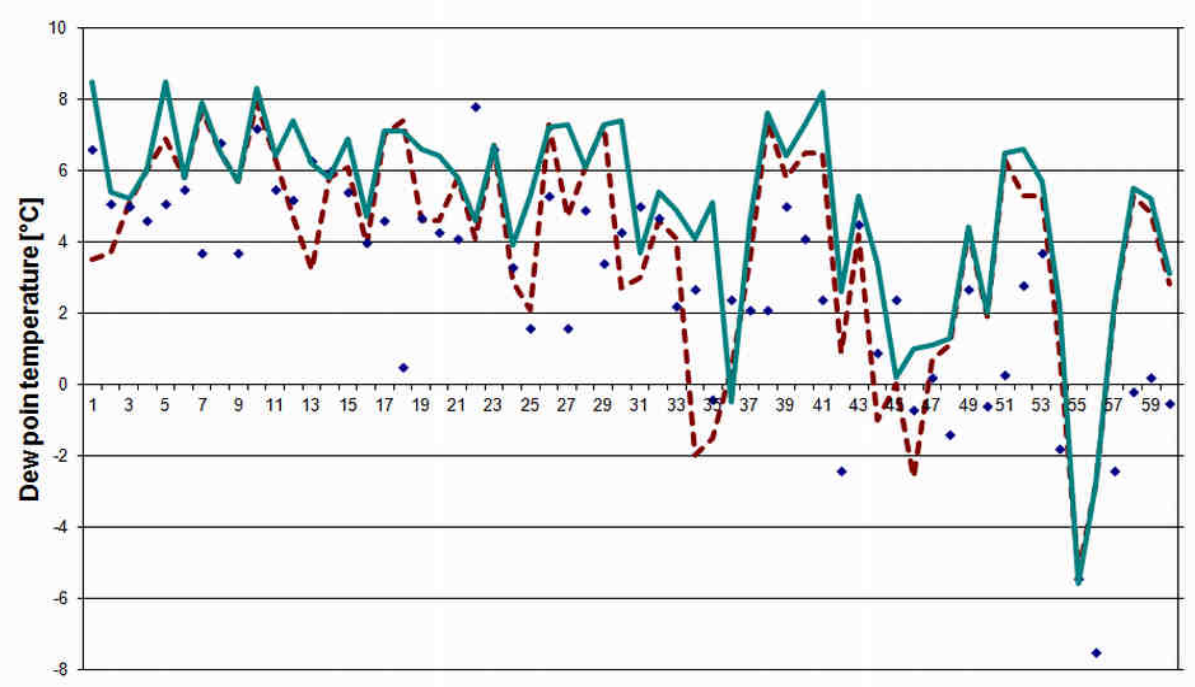

Fig. 9. Analysis of forecast of dew point temperature for April $15^{\text {th }}, 2013$. Blue diamonds represent values measured at meteorological stations (X axis - number of station). Green solid line: Darcy equation, with exponential temperature dependence. Red dashed line: parameterization with Darcy equation, exponential temperature dependence and the time correction coefficient considered 


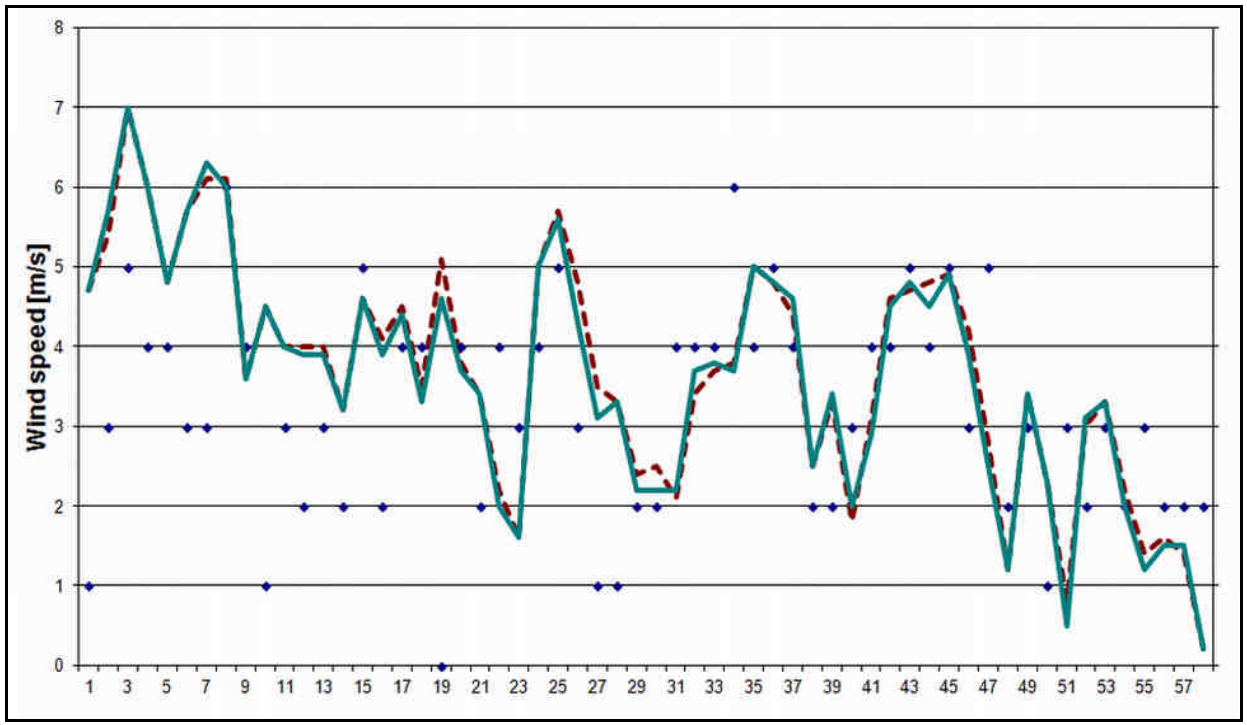

Fig. 10. Analysis of forecast of wind speed for July $1^{\text {st }}, 2013$. Blue diamonds represent values measured at meteorological stations ( $\mathrm{X}$ axis - number of station). Green solid line: Darcy equation, with exponential temperature dependence. Red dashed line: parameterization with Darcy equation, exponential temperature dependence and the time correction coefficient considered

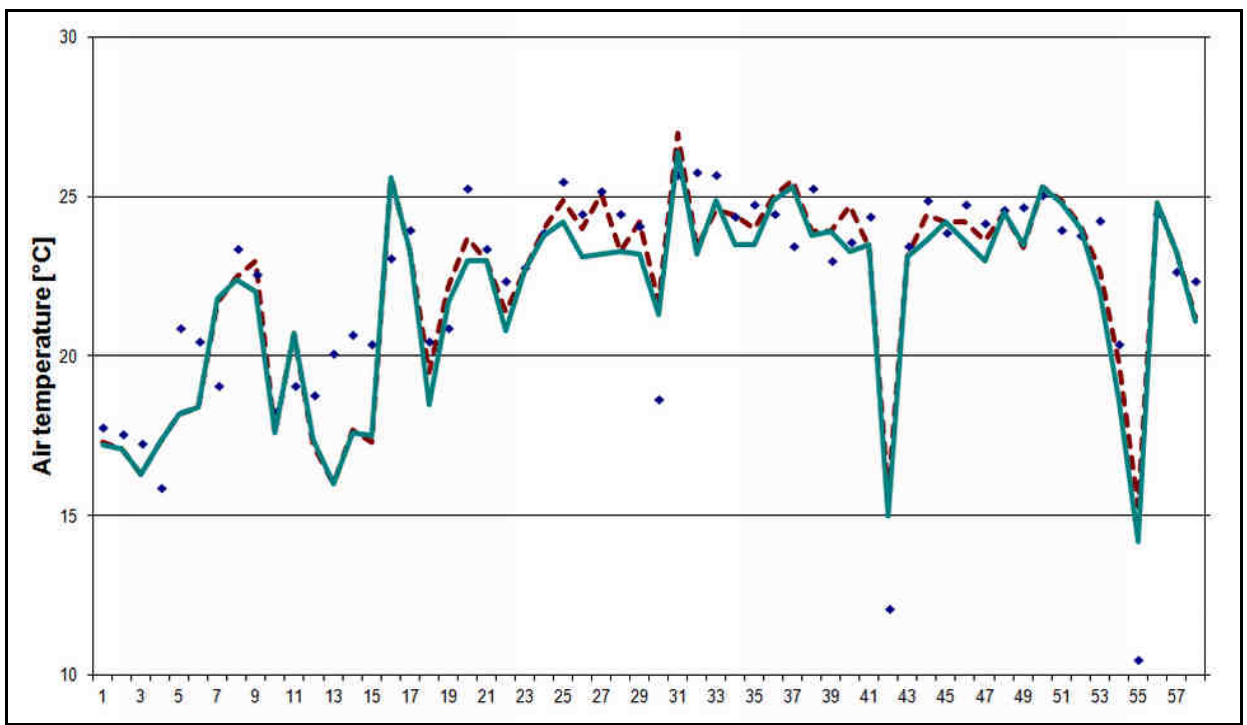

Fig. 11. Analysis of forecast of air temperature for July $1^{\text {st }}, 2013$. Blue diamonds represent values measured at meteorological stations ( $\mathrm{X}$ axis - number of station). Green solid line: Darcy equation, with exponential temperature dependence. Red dashed line: parameterization with Darcy equation, exponential temperature dependence and the time correction coefficient considered 


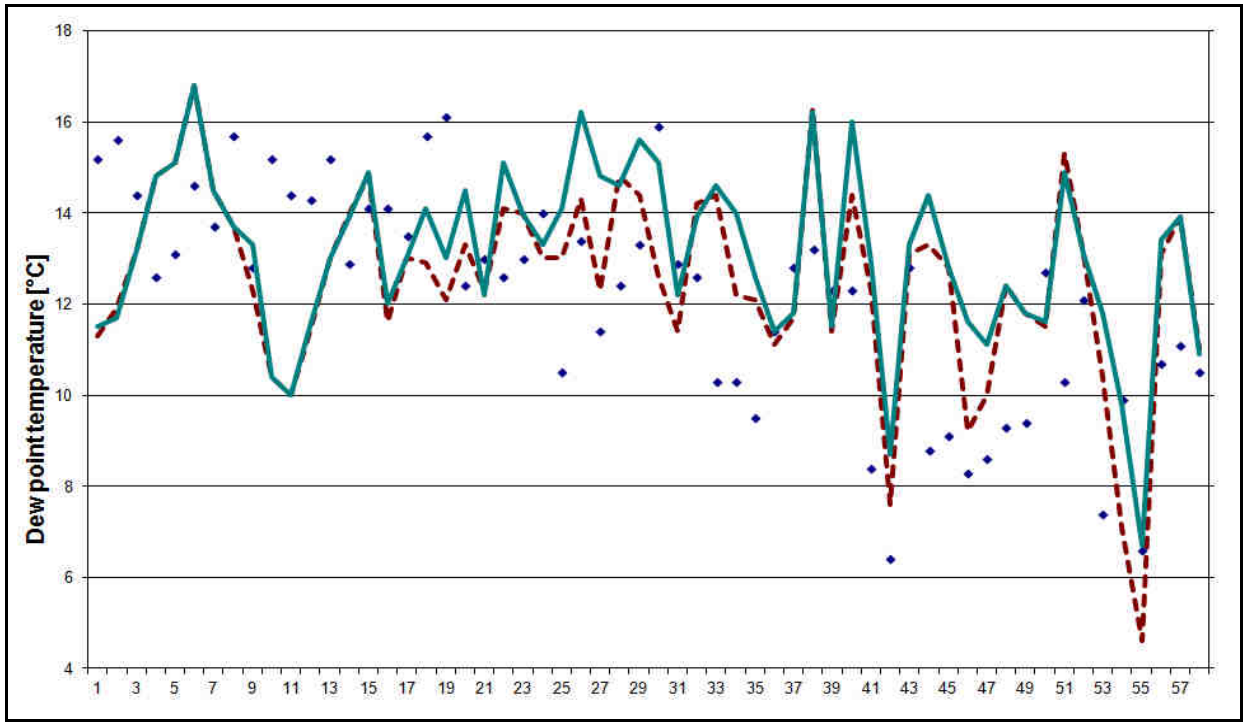

Fig. 12. Analysis of forecast of dew point temperature for July $1^{\text {st }}, 2013$. Blue diamonds represent values measured at meteorological stations ( $\mathrm{X}$ axis - number of station). Green solid line: Darcy equation, with exponential temperature dependence. Red dashed line: parameterization with Darcy equation, exponential temperature dependence and the time correction coefficient considered

As a general conclusion that can be drawn it should be stated that the change of parameterization of physical processes in the soil does not significantly affect the results of prognostic meteorological fields in the winter season when the soil temperature is below zero (at this time water is frozen in the soil and hydrological processes cease to be significant) or in case when the ground is covered with snow.

The introduction of the correcting factor that should reduce overestimation of evaporation from the soil in the morning and underestimation in the afternoon, improved forecast of meteorological fields (especially dew point), also resulted as an improvement of cloud cover and precipitation forecasts (not presented here).

\section{Conclusions}

Current parameterization of soil physical processes in TERRA_ML is a bit outdated, and, hence, cannot give adequate results (valid weather forecast). New parameterizations, one of which is presented in this paper, should take into account important physical processes in soil. The results of the first part of work, related to the parameterization of physical processes of bare soil evaporation, vertical and horizontal water transport in soil and a runoff from soil layers, described in this paper show that it is possible to obtain improvement in meteorological forests because of the appliance a proper explanation of physical phenomena occurring in soil. It should be again stressed, that in the current version of numerical weather forecasting model COSMO, numerical schemes applied for solving the Richardson equation have many weaknesses. Hence, authors still work on new numerical schemes. The quality of forecasts with used parameterization(s) does not depend 
on the circulation of the atmosphere. This issue, however, will be a subject of another study in the future.

\title{
References
}

[1] Dickinson RE. Modeling evapotranspiration for three-dimensional global climate models. In: Climate Processes and Climate Sensitivity. Hansen JE, Takahashi T, editors. Geophysical Monograph 29, 1984, Volume 5, pp. 58-72. DOI: 10.1029/GM029p0058.

[2] Stensrud DJ. Parameterization Schemes - Keys to Understanding Numerical Weather Prediction Models. Cambridge: Cambridge University Press; 2007. DOI: 10.1017/CBO9780511812590.

[3] Moene AF, van Dam JC. Transport in the Atmosphere-Vegetation-Soil Continuum. Cambridge: Cambridge University Press; 2014. DOI: dx.doi.org/10.1017/CBO9781139043137.

[4] Doms G, Foerstner J, Heise E, Herzog HJ, Mironow D, Raschendorfer M, et al. A Description of the Nonhydrostatic Regional COSMO Model. Part II: Physical Parameterization, Tech Rep., DWD, 2011. http://www.cosmo-model.org/content/model/documentation/core/cosmoPhysParamtr.pdf (access: 1.02.2015).

[5] Duniec G, Mazur A. Experiments in soil physics - case study. COSMO Newsletter. 2014;14:43-53, Consortium for Small-Scale Modeling (COSMO) materials. http://www.cosmo-model.org/ content/model/documentation/newsLetters/newsLetter14/cnl14_06.pdf (access: 1.02.2015).

\section{ZMODYFIKOWANY OPIS PROCESÓW GLEBOWYCH A JAKOŚĆ PROGNOZ NUMERYCZNYCH - PRZYPADEK ,GOŁEJ GLEBY”}

\author{
${ }^{1}$ Instytut Meteorologii i Gospodarki Wodnej - Państwowy Instytut Badawczy, Warszawa
}

\begin{abstract}
Abstrakt: Warstwy gleby i graniczna warstwa atmosfery (ABL) oddziałują ze sobą i wpływają na procesy fizyczne zarówno w glebie, jak i w atmosferze. Aktualny opis (parametryzacje) procesów fizycznych w glebie w modelu TERRA_ML (wielowarstwowy moduł gleby w modelu meteorologicznym COSMO) stworzono ponad 40 lat temu. W związku $\mathrm{z}$ tym obecnie zastosowane schematy parametryzacyjne nie dają zadowalających rezultatów (prognoz meteorologicznych). Nowe parametryzacje powinny uwzględniać procesy fizyczne w glebie (w tym mikrofizykę procesów w glebie, dynamikę płynów w ośrodkach porowatych, dynamikę gleby itp.), obieg wody w glebie i układzie gleba-roślinność-woda. Celem badań była poprawa obecnych parametryzacji TERRA_ML w modelu COSMO. W artykule przedstawiono wyniki pierwszej części prac, związanych $\mathrm{z}$ parametryzacją procesów fizycznych w przypadku parowania z powierzchni ,gołej” gleby, pionowego i poziomego transportu wody w glebie oraz odpływania wody w głąb gleby. Teoretyczny opis transportu wodnego w glebie ulega poprawie wraz z uzależnieniem dyfuzji hydraulicznej dla różnych rodzajów gleby od temperatury. $\mathrm{W}$ celu wyeliminowania niedoszacowania parowania $\mathrm{z}$ gleby w okresie popołudniowym i przeszacowania - rano dodatkowo wprowadzono czynnik korygujący zależny od czasu, poprawiający wyniki parametryzacji.
\end{abstract}

Słowa kluczowe: procesy w glebie, parametryzacja, prognozy meteorologiczne, modelowanie numeryczne, wielopoziomowy model gleby 